\title{
EFFECT OF ORGANIC AND INORGANIC NUTRIENT SOURCES ON GROWTH, YIELD AND QUALITY OF RADISH (Raphanus sativus L.) VARIETIES IN CHITWAN, NEPAL
}

\author{
S. Subedi", A. Srivastava, M.D. Sharma \& S.C. Shah \\ Agriculture and Forestry University, Chitwan, Nepal
}

\begin{abstract}
A study was conducted in Horticulture farm of Agriculture and Forestry University, Rampur, Chitwan, Nepal, during November 2015 to February 2016 by using three commercial radish varieties (All Season White, Mino Early Long White and Pyuthane Red) and five nutrient sources combination of organic manure (Poultry and Farm yard manure) and recommended dose of inorganic fertilizer (100:80:40 NPK kg ha ${ }^{-1}$ ) replicated three times in a factorial RCBD design. Most of the plant growth and yield parameters were found superior in treatments consisting poultry manure (PM) alone and in combinations with inorganic fertilizer. Treatment consisting farm yard manure (FYM) was found inferior in most of the cases. At the time of harvest, significantly higher plant height $(37.5 \mathrm{~cm})$, number of leaves per plant (24.77), root diameter $(39.01 \mathrm{~mm})$, average leaf length $(35.03 \mathrm{~cm})$, average leaf width $(12.86$ $\mathrm{cm})$ was observed in treatment consisting PM (50\%) and RDF $(50 \%)$. Similarly, root yield $\left(73.98 \mathrm{t} \mathrm{ha}^{-1}\right)$ and shoot yield $\left(62.52 \mathrm{t} \mathrm{ha}^{-1}\right)$ was also found higher in the same treatment. Among the three commercial radish varieties, Mino Early Long White was found superior in most of the growth and yield parameters viz., number of leaves per plant, biological yield, root yield, root length, root diameter, marketable root, smooth root and excellent fleshed root percentage.
\end{abstract}

Key words: Farm yard manure, poultry manure, quality root, radish varieties

\section{INTRODUCTION}

Radish (Raphanus sativus L.) is one of the most popular root vegetable of the world which can be grown from tropical to temperate region. It is grown for the consumption of its young fresh tender tuberous root which can be used as cooked or raw food as a salad. It contains good amount of vitamin- $\mathrm{C}$ and minerals like $\mathrm{P}, \mathrm{Ca}$

* Corresponding author email: shankarsubedi19@gmail.com 
and $\mathrm{K}$. It also has refreshing and diuretic properties and it can be used in homeopathy for neurological, headache, sleeplessness and chronic diarrhea (Ayub, et al., 2013 and Kumar et al., 2014)

Radish is one of the most popular root vegetable of Nepal which can be grown in winter season in Terai and throughout the year in hills of Nepal. The popularity of radish cultivation could be due its wider adaptability, low cost of production, short crop duration and can be grown in almost all type of soil without much care. Diseases and pest problems are also less in radish as compare to other vegetable crops (Shrestha and Shakya, 2004). Radish is a short duration and quick growing crop, so, the root growth and development should be uninterrupted. For this, optimum nutrition should be provided through organic, inorganic and bio-fertilizer sources. Chemical fertilizers are expensive and resulted in poor health condition of soil and water if used repeatedly. So, alternative cheap organic sources of nutrients should be used (Kumar et al., 2014).

For the use of organic manure, there are no clear recommendations available. Organic manures differ in their nutrient sources, composition as well as the mineralization rate. So, precise calculation of rate of use is important. Farmers tend to apply either too much or too low organic fertilizers. Due to which soil condition is influenced and amount of nutrients provided by organic manure is either insufficient or over dose for plants (Mbatha, 2008). Appropriate variety selection and use of optimum amount of nutrient is a crucial factor for obtaining higher yield from radish. For the optimum growth of radish roots inside the soil, optimum fertilization with both inorganic and organic sources of nutrient is necessary (Chapagain, et al., 2010). This research work was mainly focus on nutrient management (both organic and inorganic) along with appropriate varietal selection of radish for the late season sowing in Terai condition.

\section{MATERIALS AND METHODS}

A study was conducted in Horticulture farm of Agriculture and Forestry University, Rampur, Chitwan, Nepal, during November 2015 to February 2016. The location is inner Terai (plain) area with humid sub-tropical climate. The average temperature during the field research was $20.4^{\circ} \mathrm{C}$. Rainfall occurred only once during research $(7.70 \mathrm{~mm})$. The experimental site has acidic soil with low organic matter, low nitrogen and high phosphorus content.

The experiment was carried out in a RCBD with two factors viz. three radish varieties viz., All Season White, Mino Early Long White and Pyuthane Red and five nutrient sources combinations include $100 \% \mathrm{~N}$ through recommended dose of fertilizer (RDF) for radish (100:80:40 NPK ha ${ }^{-1}$ ) (Anonymous, 2012), 100\% N through PM, 50\% N through RDF $+50 \% \mathrm{~N}$ through PM, 100\% N through FYM and $50 \% \mathrm{~N}$ through RDF $+50 \% \mathrm{~N}$ through FYM. 
Table 1. Physico-chemical properties of soil sample of the experimental field

\begin{tabular}{lcc}
\hline Properties & Contents & Remarks \\
\hline Organic matter (\%) & 1.54 & Low \\
Available nitrogen $(\%)$ & 0.08 & Low \\
Available phosphorus $\left(\mathrm{kg} \mathrm{ha}^{-1}\right)$ & 360 & High \\
Available potassium $\left(\mathrm{kg} \mathrm{ha}^{-1}\right)$ & 146 & Medium \\
$\mathrm{pH}$ & 5.5 & Low (Acidic) \\
\hline
\end{tabular}

(Rating was done according to Khatri Chetri, 1991).

The FYM and PM used in this experiment were analyzed at Regional Soil Testing Laboratory, Pokhara and the results were found as following.

Table 2. Nutrient content of different organic manures used in the experiment

\begin{tabular}{lccc}
\hline \multirow{2}{*}{ Organic manures } & \multicolumn{3}{c}{ Nutrient content $(\%)$} \\
\cline { 2 - 4 } & Nitrogen & Phosphorus & Potash \\
\hline Poultry manure & 1.06 & 0.79 & 0.52 \\
FYM & 0.76 & 0.57 & 0.67 \\
\hline
\end{tabular}

After final field preparation, all the organic manure and chemical fertilizer were applied before sowing and mixed well in soil. Sowing was done at $28^{\text {th }}$ November, 2015 at the spacing of $40 \times 20 \mathrm{~cm}$. Thinning, weeding, hoeing, irrigation and other intercultural operations were done as per recommended. Final harvesting was done 60 days after sowing. Ten sample plants were taken from each plot for data recording during field growth and after harvesting. The observations were recorded during filed growth, canopy height, leaf number, rosette diameter. After harvesting of the crop, root length, diameter, leaf length, width, leaf yield, root and leaf dry weight, harvest index, marketable root, smooth surfaced roots and forked roots percentage were recorded.

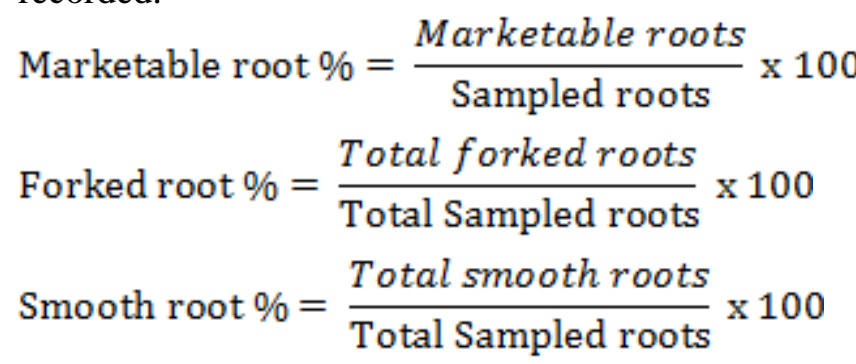

All the data were analyzed by using GENSTAT $16^{\text {th }}$ edition and MS-EXCEL 2010. 
RESULTS

\section{Plant height and number of leaves per plant}

The individual effects showed significant but interaction between varieties and nutrient sources non-significant on plant height and number of leaves per plant. (Table1). During early growth, varieties did not show any response but at the time of harvest, highest plant height was recorded in Pyuthane Red $(36.40 \mathrm{~cm})$. In case of different nutrient sources, the maximum plant height was obtained from $\mathrm{N}_{4}$ closely followed by $\mathrm{N}_{2}$ at 25 DAS but at harvest (60DAS) treatment $\mathrm{N}_{3}$ and $\mathrm{N}_{2}$ were found similar. No. of leaves showed maximum in $\mathrm{N}_{2}$ followed by $\mathrm{N}_{4}$ but no significant difference at harvest except $\mathrm{N}_{4}$ treatment which produced lower number of leaves/ plant.

Table 1. Effect of varieties and nutrient sources on plant height and number of leaves per plant at 25 DAS and 60 DAS (harvesting) at AFU, Rampur, Chitwan, 2015-2016

\begin{tabular}{lcccc}
\hline \multirow{2}{*}{ Treatments } & \multicolumn{2}{c}{ Plant height $(\mathrm{cm})$} & \multicolumn{2}{c}{ No. of leaves $\left(\right.$ plant $\left.^{-1}\right)$} \\
\cline { 2 - 5 } & $25 \mathrm{DAS}$ & $60 \mathrm{DAS}$ & $25 \mathrm{DAS}$ & $60 \mathrm{DAS}$ \\
\hline Varieties & & & & \\
$\mathrm{V}_{1}$ : All Season White & 14.46 & $33.28^{\mathrm{b}}$ & $7.427^{\mathrm{b}}$ & $23.23^{\mathrm{b}}$ \\
$\mathrm{V}_{2}$ :Mino Early Long White & 14.30 & $29.31^{\mathrm{c}}$ & $8.363^{\mathrm{a}}$ & $25.16^{\mathrm{a}}$ \\
$\mathrm{V}_{3}$ : Pyuthane Red & 13.89 & $36.40^{\mathrm{a}}$ & $8.187^{\mathrm{a}}$ & $20.69^{\mathrm{c}}$ \\
\hline $\mathrm{SEM} \pm$ & 0.39 & 1.03 & 0.19 & 0.65 \\
& & & & \\
\hline Nutrient sources & & & & \\
$\mathrm{N}_{1}\left(\mathrm{RDF}_{100 \%}\right.$ chemical $)$ & $11.17^{\mathrm{c}}$ & $32.51^{\mathrm{bc}}$ & $7.272^{\mathrm{c}}$ & $23.26^{\mathrm{a}}$ \\
$\mathrm{N}_{2}\left(\mathrm{PM}_{100 \%}\right)$ & $15.56^{\mathrm{ab}}$ & $36.23^{\mathrm{ab}}$ & $8.867^{\mathrm{a}}$ & $23.63^{\mathrm{a}}$ \\
$\mathrm{N}_{3}\left(\mathrm{PM}_{50 \%}+\mathrm{RDF}_{50 \%}\right)$ & $14.30^{\mathrm{b}}$ & $37.50^{\mathrm{a}}$ & $7.867^{\mathrm{bc}}$ & $24.77^{\mathrm{a}}$ \\
$\mathrm{N}_{4}\left(\mathrm{FYM}_{100 \%}\right)$ & $15.94^{\mathrm{a}}$ & $27.68^{\mathrm{d}}$ & $8.222^{\mathrm{ab}}$ & $20.12^{\mathrm{b}}$ \\
$\mathrm{N}_{5}\left(\mathrm{FYM}_{50 \%}+\mathrm{RDF}_{50 \%}\right)$ & $14.11^{\mathrm{b}}$ & $31.06^{\mathrm{cd}}$ & $7.733^{\mathrm{bc}}$ & $23.36^{\mathrm{a}}$ \\
\hline & & & & \\
$\mathrm{SEM} \pm$ & 0.50 & 1.33 & 0.25 & 0.84 \\
$\mathrm{CV}(\%)$ & 10.60 & 12.10 & 9.40 & 10.90 \\
\hline
\end{tabular}

Means with same letter within column do not differ significantly at $\mathrm{p}=0.05$ by DMRT.

$\mathrm{PM}=$ Poultry manure, FYM = Farm yard manure, SEM = Standard error of means, CV = Coefficient of variance,

\section{Root length, diameter and root yield}

The variety Mino Early Long White produced significantly highest root length (23.56 $\mathrm{cm})$ and root yield $\left(74.49 \mathrm{t} \mathrm{ha}^{-1}\right)$ but root diameter insignificant. Among the nutrient 
sources, root length was found insignificant but root diameter showed higher in $\mathrm{N}_{3}$ followed by $\mathrm{N}_{2}$ and $\mathrm{N}_{5}$. The maximum root yield was obtained from $\mathrm{N}_{3}$ but at par to $\mathrm{N}_{2}$ and $\mathrm{N}_{5}$, respectively. Root yield was influenced by root length and diameter as well as poultry manure. Farm yard manure and RDF failed to show higher root yield. (Table 2).

\section{Leaf length, width and leaf yield}

The Pyuthane Red variety $\left(\mathrm{V}_{1}\right)$ was produced maximum length of leaf longer (33.9 $\mathrm{cm})$ but at par to $\mathrm{V}_{3}$ where wider leaves $\left(12.23 \mathrm{~cm}\right.$ ) from $\mathrm{V}_{3}$ followed by $\mathrm{V}_{2}$. (Table 2). Among different nutrient sources, $\mathrm{N}_{3}=\mathrm{PM}_{50 \%}+\mathrm{RDF}_{50 \%}$ produced maximum length $(35.03 \mathrm{~cm})$ followed by $\mathrm{N}_{2}$ and wider leaves $(12.86 \mathrm{~cm})$ from $\mathrm{N}_{3}$ which ultimately resulted maximum leaf yield $\left(62.52 \mathrm{t} \mathrm{ha}^{-1}\right)$. The interaction effect of varieties and nutrient sources was found non-significant for leaf length, width and leaf yield.

Table 2. Effect of varieties and nutrient sources on root length, root diameter, root yield, leaf length, leaf width and leaf yield at harvesting at AFU, Rampur, Chitwan, 2015/2016

\begin{tabular}{lcccccc}
\hline Treatments & $\begin{array}{c}\text { Root } \\
\text { length } \\
(\mathrm{cm})\end{array}$ & $\begin{array}{c}\text { Root } \\
\text { diamete } \\
\mathrm{r}(\mathrm{mm})\end{array}$ & $\begin{array}{c}\text { Root } \\
\text { yield } \\
\left(\mathrm{t} \mathrm{ha}^{-1}\right)\end{array}$ & $\begin{array}{c}\text { Leaf } \\
\text { length } \\
(\mathrm{cm})\end{array}$ & $\begin{array}{c}\text { Leaf } \\
\text { width } \\
(\mathrm{cm})\end{array}$ & $\begin{array}{c}\text { Leaf } \\
\text { yield } \\
\left(\mathrm{t} \mathrm{ha}^{-1}\right)\end{array}$ \\
\hline Varieties & & & & & & \\
$\mathrm{V}_{1}$ : All Season White & $21.42^{\mathrm{b}}$ & 33.99 & $47.77^{\mathrm{b}}$ & $31.48^{\mathrm{a}}$ & $9.75^{\mathrm{b}}$ & $35.79^{\mathrm{b}}$ \\
$\mathrm{V}_{2}$ : Mino Early Long & $23.56^{\mathrm{a}}$ & 37.78 & $74.49^{\mathrm{a}}$ & $27.77^{\mathrm{b}}$ & $11.51^{\mathrm{a}}$ & $49.58^{\mathrm{a}}$ \\
White & & & & & & \\
$\mathrm{V}_{3}$ : Pyuthane Red & $20.00^{\mathrm{b}}$ & 36.27 & $53.35^{\mathrm{b}}$ & $33.90^{\mathrm{a}}$ & $12.23^{\mathrm{a}}$ & $50.20^{\mathrm{a}}$ \\
\hline $\mathrm{SEM} \pm$ & 0.65 & 1.10 & 4.38 & 0.94 & 0.31 & 3.32 \\
\hline $\mathrm{Nutrient}$ sources & & & & & & \\
$\mathrm{N}_{1}\left(\mathrm{RDF}_{100 \% \text { chemical }}\right)$ & 19.99 & $33.83^{\mathrm{bc}}$ & $49.98^{\mathrm{b}}$ & $30.51^{\mathrm{b}}$ & $11.46^{\mathrm{b}}$ & $43.00^{\mathrm{bc}}$ \\
$\mathrm{N}_{2}\left(\mathrm{PM}_{100 \%}\right)$ & 22.44 & $37.64^{\mathrm{ab}}$ & $68.53^{\mathrm{a}}$ & $34.28^{\mathrm{a}}$ & $11.46^{\mathrm{b}}$ & $54.49^{\mathrm{ab}}$ \\
$\mathrm{N}_{3}\left(\mathrm{PM}_{50 \%}+\mathrm{RDF}_{50 \%}\right)$ & 22.53 & $39.01^{\mathrm{a}}$ & $73.98^{\mathrm{a}}$ & $35.03^{\mathrm{a}}$ & $12.86^{\mathrm{a}}$ & $62.52^{\mathrm{a}}$ \\
$\mathrm{N}_{4}\left(\mathrm{FYM}_{100 \%}\right)$ & 21.04 & $33.13^{\mathrm{c}}$ & $42.95^{\mathrm{b}}$ & $25.95^{\mathrm{c}}$ & $9.35^{\mathrm{c}}$ & $25.90^{\mathrm{d}}$ \\
$\mathrm{N}_{5}\left(\mathrm{FYM}_{50 \%}+\mathrm{RDF}_{50 \%}\right)$ & 22.30 & $35.46^{\mathrm{abc}}$ & $57.25^{\mathrm{ab}}$ & $29.49^{\mathrm{b}}$ & $10.67^{\mathrm{b}}$ & $40.03^{\mathrm{c}}$ \\
\hline $\mathrm{SEM}^{\mathrm{N}} \pm$ & $\mathrm{NS}$ & 1.43 & 5.65 & 1.21 & 0.39 & 4.29 \\
$\mathrm{CV}(\%)$ & 11.60 & 11.90 & 29.00 & 11.70 & 10.70 & 28.50 \\
\hline
\end{tabular}

Means with same letter within column do not differ significantly at $\mathrm{p}=0.05$ by DMRT.

$\mathrm{PM}=$ Poultry manure, $\mathrm{FYM}=$ Farm yard manure, $\mathrm{SEM}=$ Standard error of means, $\mathrm{CV}=$ Coefficient of variance 


\section{Dry weight of root and leaf per plant}

The variety mino early long white $\left(\mathrm{V}_{2}\right)$ produced significantly highest root dry weight (15.13 g plant $\left.{ }^{-1}\right)$ and leaf dry weight (12.23 $\left.\mathrm{g} \mathrm{plant}^{-1}\right)$ as compared to other varieties. Nutrient sources effect was non-significant for root dry weight but in case of leaf dry weight $\mathrm{PM}_{100 \%}$ treatment produced maximum value $\left(11.56 \mathrm{~g} \mathrm{plant}^{-1}\right)$ but at par to other treatments except $\mathrm{N}_{4}$ followed by $\mathrm{N}_{5}$ and $\mathrm{N}_{3}$, respectively (Table 3 ).

\section{Percentage of marketable roots, smooth roots and forked roots}

In case of individual factors, higher marketable roots $(84.67 \%)$ and smooth surfaced roots $(44.89 \%)$ were produced by Mino Early Long White and lowest percentage was produced by Pyuthane Red (68.60\% and55.36\%, respectively) (Table $3)$. The effect of nutrient sources on marketable root, smooth root and forked root was found insignificant. The interaction effect of varieties and nutrient sources was also found non-significant.

\section{Harvest index}

The FYM containing treatments, $\mathrm{FYM}_{100 \%}(60.88 \%)$ and $\mathrm{FYM}_{50 \%}+\mathrm{RDF}_{50 \%}(57.69 \%)$ showed significantly higher harvest index than the other treatments (Table 3). Varietal effects was also found significant in case of harvest index. Mino Early Long White $\left(\mathrm{V}_{2}\right)$ produced significantly highest harvest index $(60.72 \%)$ followed by All Season White (57.27\%) and Pyuthane Red (51.54\%).

Table 3. Effect of varieties and nutrient sources on root and leaf dry weight, marketable, smooth, forked root percentage and harvest index at AFU, Rampur, Chitwan, 2015/2016

\begin{tabular}{|c|c|c|c|c|c|c|}
\hline Treatments & $\begin{array}{l}\text { Root dry } \\
\text { weight } \\
\left(\text { g plant }^{-1}\right)\end{array}$ & $\begin{array}{c}\text { Leaf dry } \\
\text { weight } \\
\left(\text { g plant }^{-1}\right)\end{array}$ & $\begin{array}{c}\text { Marketable } \\
\operatorname{root}(\%)\end{array}$ & $\begin{array}{l}\text { Smooth } \\
\operatorname{root}(\%)\end{array}$ & $\begin{array}{l}\text { Forked } \\
\text { root }(\%)\end{array}$ & $\begin{array}{c}\text { Harvest } \\
\text { index }\end{array}$ \\
\hline \multicolumn{7}{|l|}{ Varieties } \\
\hline $\mathrm{V}_{1}$ : All Season White & $11.00^{\mathrm{b}}$ & $8.43^{\mathrm{b}}$ & $84.67^{\mathrm{a}}$ & $67.94^{\mathrm{b}}$ & 31.28 & $57.27^{\mathrm{b}}$ \\
\hline $\begin{array}{l}\mathrm{V}_{2}: \text { Mino Early Long } \\
\text { White }\end{array}$ & $15.13^{\mathrm{a}}$ & $12.23^{\mathrm{a}}$ & $94.33^{\mathrm{a}}$ & $84.89^{\mathrm{a}}$ & 37.72 & $60.72^{\mathrm{a}}$ \\
\hline $\mathrm{V}_{3}$ : Pyuthane Red & $10.67^{\mathrm{b}}$ & $8.47^{\mathrm{b}}$ & $68.60^{\mathrm{b}}$ & $55.36^{\mathrm{b}}$ & 33.69 & $51.54^{\mathrm{c}}$ \\
\hline $\mathrm{SEM} \pm$ & 1.00 & 0.82 & 4.47 & 5.81 & 6.61 & 1.08 \\
\hline \multicolumn{7}{|l|}{ Nutrient sources } \\
\hline $\mathrm{N}_{1}\left(\mathrm{RDF}_{100 \% \text { chemical }}\right)$ & 11.33 & $10.56^{\mathrm{a}}$ & 81.94 & 66.39 & 35.56 & $53.93^{\mathrm{b}}$ \\
\hline $\mathrm{N}_{2}\left(\mathrm{PM}_{100 \%}\right)$ & 13.00 & $11.56^{\mathrm{a}}$ & 89.60 & 70.87 & 34.21 & $56.02^{\mathrm{b}}$ \\
\hline
\end{tabular}




\begin{tabular}{lcccccc}
\hline \multicolumn{1}{c}{ Treatments } & $\begin{array}{c}\text { Root dry } \\
\text { weight } \\
\left(\mathrm{g} \mathrm{plant}^{-1}\right)\end{array}$ & $\begin{array}{c}\text { Leaf dry } \\
\text { weight } \\
\left(\mathrm{g} \mathrm{plant}^{-1}\right)\end{array}$ & $\begin{array}{c}\text { Marketable } \\
\text { root }(\%)\end{array}$ & $\begin{array}{c}\text { Smooth } \\
\text { root }(\%)\end{array}$ & $\begin{array}{c}\text { Forked } \\
\text { root }(\%)\end{array}$ & $\begin{array}{c}\text { Harvest } \\
\text { index }\end{array}$ \\
\hline $\mathrm{N}_{3}\left(\mathrm{PM}_{50 \%}+\mathrm{RDF}_{50 \%}\right)$ & 13.78 & $9.94^{\mathrm{ab}}$ & 77.78 & 69.44 & 49.17 & $54.03^{\mathrm{b}}$ \\
$\mathrm{N}_{4}\left(\mathrm{FYM}_{100 \%}\right)$ & 11.89 & $6.89^{\mathrm{b}}$ & 85.56 & 74.17 & 23.33 & $60.88^{\mathrm{a}}$ \\
$\mathrm{N}_{5}\left(\mathrm{FYM}_{50 \%}+\mathrm{RDF}_{50 \%}\right)$ & 11.33 & $9.61^{\mathrm{ab}}$ & 77.78 & 66.11 & 28.89 & $57.69^{\mathrm{ab}}$ \\
\hline $\mathrm{SEM} \pm$ & 1.30 & 1.05 & 5.78 & 7.50 & 8.53 & 1.39 \\
$\mathrm{CV}(\%)$ & 31.90 & 32.60 & 21.00 & 32.40 & 74.80 & 7.40 \\
\hline
\end{tabular}

Means with same letter within column do not differ significantly at $\mathrm{p}=0.05$ by DMRT.

$\mathrm{PM}=$ Poultry manure, FYM = Farm yard manure, $\mathrm{SEM}=$ Standard error of means, $\mathrm{CV}=$ Coefficient of variance

\section{Varietal comparison}

The varietal comparison of radish was done on the basis of various morphological and sensory characters. The detail comparison is given below.

Table 4. Characterization of three commercial radish varieties at AFU, Rampur, Chitwan, 2015-2016

\begin{tabular}{lccc}
\hline Characterization & All season white & Mino early long white & Pyuthane red \\
\hline Leaf attitude & Semi erect & Spreading & Erect \\
Leaf colour & Dark green & Faint green & Green \\
Hairiness of leaf & Rare & Dense & Rare \\
Nature of spine & Soft & Soft & Soft \\
Shape of leaf segment & Triangular & Triangular & Triangular \\
Leaf shape & Flat round & Flat round & Oval \\
Leaf margin & Serrated & Serrated & Entire \\
Spinyness of the stalk & Rare & Dense & Absent \\
Colour of stalk & Green & Green & Red \\
Root shape & Long & Long & Medium \\
Skin colour & White & White & Red \\
Flesh colour & White & White & Reddish white \\
Shape of root shoulder & Convex & Convex & Convex \\
Pungency of root & Moderate pungent & Moderate pungent & Less pungent \\
TSS $\left({ }^{0}\right.$ Brix $)$ & 5.12 & 5.22 & 6.14 \\
\hline
\end{tabular}




\section{DISCUSSION}

The Pyuthane red variety has longer and entire leaves with erect growth habit, which produced highest plant height, leaf length, width and leaf yield, while All Season White and Mino Early Long White has semi-erect growth habit and serrated leaves. Highest number of leaves was produced by Mino Early Long White which ultimately produced highest leaf dry weight per plant. Similarly, longer and wider roots with maximum root yield was produced by same variety which performed better in Chitwan condition than the other two varieties. Besides, the variety Mino Early Long White performed better than other two varieties due to higher percentage of marketable roots and smooth surfaced roots. Pyuthane Red variety performed poor in Chitwan condition due to lowest percentage of marketable and smooth surfaced roots. The variety All Season White was produced lowest percentage of forked roots.

Among the different nutrient sources used, PM containing treatments performed best than other treatments either alone or in combination with chemical fertilizer. Treatment comprises of 50\% PM and 50\% RDF produced longer and wider leaves as well as roots which gives ultimately highest yield of root and leaf. Higher plant height was observed in PM treated plots alone and with combination with inorganic fertilizer than the other treatments. This might be due to the higher nutrient content (NPK and other micro nutrients) and higher organic matter content of PM which are essential for plant growth. Similar results also reported by Zeid et al., 2015, who also found highest plant height of radish when poultry manure is used either alone or in combination with inorganic fertilizer.

The results showed that, longer and wider roots were produced by treatments consisting poultry manure alone or in combination with chemical fertilizer produced longest and widest roots. Production of longest and widest roots by PM consisting treatments leads to highest leaf and root yield. The applied organic manure improves soil physical condition by increasing soil porosity and decreasing bulk density which make suitable for smooth root penetration and growth inside the soil. The chemical fertilizer used along with organic manure supports the plant growth and contributes to higher yield. Among the different organic manure, PM helps to improve soil condition, increase water holding capacity of soil and provide more macro as well as micro nutrients than FYM. PM produced better results than pure inorganic fertilizer treatment, because it can provide all 13 types of soil micronutrients in considerable amount which inorganic fertilizer can't provide (Chastain, et al., 1999). Sylvestre et al. (2015) also reported that highest root yield of carrot was found when treated with PM and inorganic fertilizer as well as poultry manure leads to ease of root penetration and good soil moisture.

\section{CONCLUSION}

From this experiment the hybrid variety mino early long white of radish performed best in Chitwan late sowing condition due to higher yield and quality production. 
Besides, poultry manure should be used along with inorganic fertilizer with precise calculation of recommended dose of nutrition. Poultry manure alone can produce better results than chemical fertilizer alone.

\section{ACKNOWLEDGEMENTS}

This research was supported under grant from Department of Research and Extension (DOREX). I would like to express my sincere gratitude to Department of Horticulture for providing an opportunity to conduct this research and express my sincere appreciation to Campus Administration. I would like to thank my advisory team especially Prof. Dr. Arvind Srivastava for his inspirations and assistances during research and manuscript preparation.

\section{REFERENCES}

Anonymous, (2012).Agribusiness Promotion and Statistics Division.20Vegetable Farming Technology. Kathmandu, Nepal: Ministry of Agriculture and Cooperative. www.moac.gov.np.

Ayub, R.A., Spinardi, B., and Gioppo, M. (2013).Storage and fresh cut radish. Acta Scientiarum Agronomy., 35(2): 241-245.

Chapagain, T.R., Piya, S., Dangal, N.K., Mandal, J.L., and Chaudhary, B.P.(2010). Comparison of commercial and local varieties of radish at different levels of manures and fertilizers. Nepal Journal of Science and Technology, 11. 51-56.

Chastain, J.P., Camberato, J.J., and Skewes, P. (1999).Poultry manure production and nutrient content. (https://www.researchgate.net/profile/James_Camberato/publication/265021539_3b1_Poultry_Manure_Production_and_Nutrient_Content_NUTRIENT_CONTENT_OF _POULTRY_MANURE/links/543d1d9b0cf2c432f7424eb9.pdf?origin=publication_de tail). (Accessed 9 September, 2016).

Sylvestre, Habimana., Constance, Mukeshimana., Esdras, Ndayisaba., and Athanase, Nduwumuremyi. (2015).Effect of poultry manure and NPK (17-17-17) on growth and yield of carrot in Rulindo district, Rwanda. International journal of novel research in life sciences., 2(1), 42-48.

Kumar, Sandeep., Maji, Sutanu., Kumar, Sanjay., and Singh, Harsh Deep. (2014).Efficacy of organic manures on growth and yield of radish (Raphanus sativus L.) cv. Japanese white. International journal of plant sciences., 9(1), 57-60.

Shrestha, M.M., and Shakya, S.M. (2004).Response of radish crop var. fourty days to transplanting age and detopping in respect to seed yield. In: Proceedings of the fourth national workshop on horticulture (2-4 March 2004) pp. 377-379.

Zeid, H.A., Wafaa, H.M., Abou El Seoud, I.I., and Alhadad, W.A.A. (2015).Effect of organic materials and inorganic fertilizers on the growth, mineral composition and soil fertility of radish plants (Rapahine's sativus) grown in sandy soil. Middle East journal of Agriculture., 4(1), 77-87. 